\title{
Milli Kütüphane'de Görme Engellilere Yönelik Konuşan Kitaplık Bölümü Hizmetinin Değerlendirilmesi ve Kullanıcı Memnuniyeti Araştırması*
}

\author{
Evaluation of the Talking Library Department Service \\ for Visually Impaired Users in National Library and the \\ User Satisfaction Survey
}

\author{
Fatma Gamze TEZCAN** ve Yüksel TANRIKULU*** \\ “Gözlerimi sımsıkı kapadım \\ Elime bir kitap aldım \\ Ben dinliyorken \\ Gören gözlerim onu çoktan okumuş" \\ Fatma Gamze TEZCAN
}

\begin{abstract}
Öz
Bu çalışmanın amacı görme engelli kullanıcılara yönelik kütüphane hizmetlerini Milli Kütüphane'de bulunan Konuşan Kitaplık Bölümü'nü ele alarak değerlendirmek ve bu değerlendirmeler doğrultusunda kullanıcı memnuniyeti araştırması yapmaktır. Bu çerçevede Milli Kütüphane görme engelli kullanıcılarına Kasım-Aralık 2010 tarihlerinde anket uygulanmıştır. Altı Nokta Körler Derneği üyeleri, Görme Özürlüler Rehabilitasyon Merkezi görevlileri, Mitat Enç Görme Engelliler İlköğretim Okulu öğrencileri ve öğretmenleri, Cumhuriyet Lisesi öğrencileri ve Milli Kütüphane görme engelli personeli ve orada bulunan görme engelli kullanıcılar ile yüz yüze görüşülüp anketleryapılmış, ayrıca Milli Kütüphane Konuşan Kitaplık personeli aracılığı ile anketler e-mail yoluyla Konuşan Kitaplık Bölümü üyelerine gönderilerek anketler yanıtlanmıştır. Toplam 45 görme engelli birey ile yüz yüze görüşülüp bunlar arasında Milli Kütüphane Konuşan Kitaplığı kullanan ya da kullanmış olan 32 görme engelli kullanıcıya anket yapılmıştır. Elde edilen bulgular ile Milli Kütüphane Konuşan Kitaplık Bölümü kullanıcılarının memnuniyetleri değerlendirilmiştir. Anket sonuçların da Milli Kütüphane Konuşan Kitaplık Bölümü görme engellilere yönelik hizmetleri yeterli olmadığı ortaya çıkmış ve bu kapsam da çözüm önerileri verilmiştir.
\end{abstract}

Anahtar sözcükler: Konuşan kitaplık, Görme engelli kullanıılar, Kullanıcı memnuniyeti , Milli Kütüphane

\footnotetext{
* İlgili çalışma 2011 yılı Genç ÜNAK makale yarışmasında birinci olmuştur.

** Hacettepe Üniversitesi, Edebiyat Fakültesi, Bilgi ve Belge Yönetimi Bölümü gamse_tezcan@hotmail.com

*** Hacettepe Üniversitesi, Edebiyat Fakültesi, Bilgi ve Belge Yönetimi Bölümü, yksl.tanrikulu@hotmail.com
} 


\begin{abstract}
The purpose of this study is to evaluate the library services for the visually handicapped users by handling the "Talking Library" department in National Library and carry out a user satisfaction survey in respect of these evaluations. In this context, a questionnaire has been applied on November-December 2010 for visually handicapped users of National Library. A face to face interview was held with Altı Nokta Association of The Blind members, the staff of Rehabilitation Center for Visually handicapped, the students and teachers of Mitat Enç Visually Disabled Primary School, the students of Cumhuriyet High School and the visually disabled personnel of National Library and the other visually disabled users there, and some surveys were applied. Besides, the questionnaires were sent to the members of "Talking Library" department by e-mails via the personnel of "Talking Library" and answered. Totally 45 visually disabled people were mutually interviewed and among them 32 visually disabled users who have been using National Library Talking Library service or the ones used it before answered the questionnaire. By the findings obtained from the questionnaire, the user satisfaction has been assessed. The results of the questionnaire have revealed that the service for the visually disabled users in National Library Talking Library Department is not satisfactory and sufficient and some solutions have been offered within this scope.
\end{abstract}

Keywords: Talking library, Visually impaired users, User satisfaction, National Library

\title{
Giriş
}

Bireyin toplum hayatına tam olarak katılabilmesi, toplum hayatındaki yeri ve konumunu alması, toplum hayatının tüm bireylere eşit olarak sunduğu faaliyet, olanak ve hizmetlerden yararlanabilmesi, bunlara ulaşabilmesi aynı zamanda kendinin de topluma hizmet sunabilmek için çalışması, çabalaması ve fikir üretmesi gerekir. "Bilgi çağı" diye adlandırdığımız günümüzde toplumsal hayata aktif olarak katılmanın en büyük gereklerinden biri de bilgiye erişimdir. Bireyler bilgiye eriştiği müddetçe bilgiye olan ihtiyacını giderir ve hem toplum içinde hem de bireysel hayatında ilerlemesini sürdürür. Bilgi ihtiyaç ve gereksinimi yaşam boyu sürüp gider bu gereksinim hiçbir yaşta hiçbir bireyde yok olmaz her birey için yaşam boyu bir eğitim söz konusudur. Her birey ne durumda olursa olsun (eğitim düzeyi, cinsiyeti, evli ya da bekâr oluşu, sağlıklı ya da sağlıksız oluşu, herhangi bir engelinin olup olmayışı gibi...) bilgiye ihtiyaç duyar, merak ettiği sorulara yanıt bulmak ister. Bunun için de ihtiyaç duyduğu bilgiye erişebileceği yerler arar. Yaşadığımız bilgi çağında her gün milyonlarca bilgi üretilmekte, milyonlarca bilgi arasında doğru organize edilmiş, erişilebilirliği her birey için sağlanmış bilgiye duyulan ihtiyaç gün geçtikçe artmaktadır.

Bilgi toplumunun en önemli gereklerinden biri gereksinim duyulan doğru bilgiye, doğru kapsamda, doğru zaman da erişilebilirliği sağlamaktır. Bu görevi de en iyi şekilde yerine getirmeyi önemli meslek etiği ilkesi sayan bilgi merkezleri; kütüphaneler, arşivler, dokümantasyon ve enformasyon merkezleri adlarıyla karşımızı çıkmaktadır. Her bilgi merkezinin görevi, amacı, kullanıcı grubu farklılıklar göstermekle beraber temelde hepsi "bilgiye erişim” için hizmet vermektedir. Çalışmamız açısından ele alacağımız bilgi 
merkezi kütüphanelerdir. Bilgi merkezlerinden kütüphanelerin temel amacı; bireylerin ve grupların dinlenme, boş zamanlarını değerlendirme eğitim, bilgi ve kişisel gelişim konularındaki gereksinimlerini karşılamak için çeşitli ortamlarda kaynak ve hizmet sağlamaktır. Kütüphaneler, bireylerin çok geniş biçimde çeşitli bilgi, düşünce ve fikirlere erişimlerini sağlayarak, demokratik bir toplumun geliştirilmesinde ve yaşatılmasında önemli rol oynar (Yılmaz, 2007, s.22). Buna göre kütüphaneler hiçbir ayrım gözetmeden bireylerin ve tüm kullanıcı gruplarının bilgi gereksinimlerini karşılama da hizmet vermekle yükümlüdürler.

Kütüphaneler içinde önemli ve ayrı bir yere sahip olan Milli Kütüphane Şenalp (2002, s.465)'in Akbulut (1984)'dan aktardığına göre; ülkelerinin tarihi, politik ve sosyal yapılarına göre, kuruluş ve gelişmelerinde, bazı farklılıklar gözlense de, genel olarak; ülke yayınlarını yasal yolla, ya da diğer düzenlemelerle, eksiksiz olarak toplamak, korumak ve bunlardan yararlanmayı sağlamakla yükümlüdürler. Aynı zamanda, ülkelerinin fikir ve sanat ürünlerini toplayıp gelecek kuşaklara aktarılmasına ve kültür mirasının oluşmasına da katkıda bulunurlar. Buna göre Milli Kütüphane'nin önemli görevlerinden biri de tüm kütüphanelerin de görevi olduğu gibi barındırdığı bilgi hazinesini kendi kuralları çerçevesinde bireylerin yararlanabilmesini sağlamak, ülkelerin fikir ve sanat eserlerini toplayıp gelecek kuşaklara aktarmaktır. Milli Kütüphane ‘nin kuruluş kanununda özel olarak yer almamasına rağmen "gelecek kuşaklar" kavramıyla da aslında olması gereken, açıklıkla belirtmiş olduğu tüm görevlerinin yanı sıra Milli Kütüphane, bünyesinde görme engellilere yönelik hizmet veren bir bölümü de barındırmaktadır. Milli Kütüphane Konuşan Kitaplık Bölümü bu kapsamda görme engellilere uygun koleksiyon, personel, hizmet, sunulan ortam, teknik ve teknolojik alt yapı, bunlar içinde gerekli olan bütçe ile görme engelli kullanıcılarına hizmet vermeye çalışmaktadır. Konuşan kitaplık koleksiyonunda Braille Alfabesi ile basılmış eserler, CD ve kasetlere aktarılmış sesli kitaplar barındırmakta bu sesli kitaplar elektronik ortamda dinlenmekte, istenirse de kullanıcılar bilgisayarlarına indirip sesli kitaplardan yararlanmaktadır.

Ülkemizde görme engellilere yönelik bilgi hizmeti sunma henüz çok yetersiz ve sınırlıdır. Mevcut durumun iyileştirilmesi, geliştirilmesi konusunda en büyük görevi kütüphaneler için de hiç kuşkusuz ki Milli Kütüphane üstlenmelidir. Bu proje kapsamında görme engelli kullanıcılara yönelik kütüphane hizmeti veren Milli Kütüphane'de bulunan Konuşan Kitaplık Bölümü ele alıp değerlendirilecek ve bu değerlendirmeler doğrultusunda kullanıcı memnuniyeti araştırması yapılacaktır. Milli Kütüphane Konuşan Kitaplık Bölümü’nün hizmetleri, eksiklileri, yapılan eleştiriler, fikir ve düşünceler aktarılmakta ve mevcut durumu iyileştirmek için öneri ve çözümler sunulmaktadır.

\section{Milli Kütüphane Konuşan Kitaplık Bölümü}

Bir ülkenin gelişmişlik düzeyini gösteren en önemli etkenlerden biri, o ülkedeki kitap okuma oranının yüksek olmasıdır. Gelişmiş ülkeler, kitap okuma oranlarını yükseltmek 
için çeşitli çalışmalar yapmaktadırlar. Bu çalışmalarda, engellileri de asla göz ardı etmemektedirler. Dünyanın hemen hemen her ülkesinde engellilerin de en yüksek düzeyde kitap okuma olanağına kavuşmaları için yoğun bir çaba sarf edilmektedir. Ülkemizde de çeşitli resmi kurum veya kuruluşlar ile görme engellilere ait derneklerde, sesli kitaplıklar bulunmaktadır. Milli Kütüphane de bunlardan biridir (Bakırcı, 2009, s.100101). Milli Kütüphane ulusal yayınların denetlenmesinden bu yayınların kullanıcıların hizmetine sunulmasına kadar birçok alanda görev yapan bir kurumdur. Milli Kütüphane bünyesinde görme engellilere yönelik hizmet veren bir bölüm barındırmaktadır. Milli Kütüphane'nin bu bölümündeki hizmetleri ile görme engelliler; her bir birey için geçerli olan bilgi edinme hakkını, sağlıklı bireyler gibi engelsiz bir hayat sürme hakkını, engelsiz bir hayatta yaşam hakkını ve sunulan hizmetlerden hiçbir ayrım gözetmeden yararlanma hakkını Milli Kütüphane'nin hizmet ve faaliyetleri çerçevesi içinde sahip olmuşlardır.

Milli Kütüphane Konuşan Kitaplık Bölümü‘nden yaralanabilmek için öncelikle üye olmak gerekmektedir. Üye olabilmek için de bireyler görme engelli olduğuna dair raporu, özel kimlik kartını Konuşan Kitaplık Bölümü’ne getirmek ya da faksla göndermek zorundadır. Görme engelli olup olmadığı tespit edildikten sonra birey görme engelli ise üyelik formunu doldurup üyelik işlemi tamamlanmaktadır. Böylece kütüphane içinde ve dışında koleksiyona erişebilmektedirler. Kullanıcılar kendilerine verilen şifreler ile istedikleri sesli eserleri elektronik ortam da dinleyebildikleri gibi, kendi bilgisayarlarına da kopyalama olanağına sahiptirler (toplam görme engelli üye sayısı: 658).

Görme engelli okuyuculara hizmet veren Konuşan Kitaplık Bölümü Kitap Dışı Materyaller Şube Müdürlüğü'ne bağlı olarak hizmet vermektedir. Bu bölümün koleksiyonunda gönüllü okuyucular tarafından seslendirilen 11.000 adet kasetten oluşan 1.100 adet sesli kaset kitap bulunmaktadır. Bu sesli kaset kitaplardan 387 adedi dijital ortama aktarılmış olup; halen dijital ortama aktarma çalışmalarına devam edilmektedir(http://www.mkutup.gov.tr).

Braille yabancı kitaplar bağış ya da satın alma yoluyla sağlanmaktadır. Görme engelli kullanıcılar için 1990 yılından bu yana basılı yabancı dergiler gelmektedir. Yerli dergiler arasından, genelde derneklerin çıkarmış olduğu Büyüteç, Altınokta Sesi, Altın Kalemler dergileri kütüphaneye ücretsiz olarak gelmektedir. Ayda 50-60 civarında görme engellinin kullandığı kütüphanede bulunamayan kaynaklar için kullanıcılar istek yapabilmektedir (Büyüksan, s.52). Braille Alfabesi ile basılmış çok az sayıda kaynak bulunmaktadır. Türkçe ve yabancı dilde kitaplar, dergiler, haritalar ve notalardan oluşan yaklaşık 500 Braille eserden oluşan bir koleksiyon mevcuttur. Braille alfabesiyle yazılmış yeni kitap bulunmamakta daha çok güncelliğini kaybetmiş çok eski ders kitapları ve İngilizce kitaplar ile sözlükler bulunmaktadır. Zaten Braille Alfabesi ile basım yapılmamakta kütüphane bünyesinde Braille Matbaası bulunmamaktadır. Bu kütüphane ve görme engelli kullanıcılar için çok büyük bir eksikliktir. Bu eksikliği bir nebze giderebilen Braille Printer vardır. Bu printer sayesinde Braille Alfabesi ile 
basılmamış kaynaklar Braille Printer sayesinde Braille Alfabesine dönüştürülerek çıktısı alınmaktadır.

Koleksiyon da az görenler için büyük puntolar ile yazılmış hiçbir materyal bulunmamaktadır. Az gören kullanıcılar bu eksiklikten çok şikâyetçidir. Büyük puntolu kaynaklar koleksiyon da yer alsa çoğunlukla az gören kullanıcılar kütüphaneyi aktif olarak kullanmaya başlarlar. Bu da kütüphanenin gelişmesinde ve hizmetlerinin çok yönlü artmasında önemli bir rol oynar.

Yurt dışındaki kütüphane hizmetlerin de çevrimiçi danışma kaynakları, elektronik posta/dergi, büyük puntolu eser istendiğinde üretme ve hemen kullanıcıya gönderme gibi hizmetler verilmekte ancak böyle bir hizmet Milli Kütüphane'de bulunmamaktadır.

Görme engelliler sesli kitapları kütüphaneden ödünç alabilmektedirler. Kütüphaneye gelmeden de yalnız üye olmak koşuluyla istenilen sesli materyal kullanıc Türkiye'nin neresinde olursa olsun hiçbir posta ücreti alınmadan adresine teslim edilmektedir.

Kitaplar kullanıcı istekleri dikkate alınarak seslendirilmektedir. İstedikleri kitapları bildirmeleri için kullanıcılara e-posta gönderilmekte ve geri dönen istekler değerlendirilmektedir. Son yıllarda en çok tercih edilenler ise sınavlara hazırlık kitaplarıdır.

Milli Kütüphane Konuşan Kitaplık Bölümü'nde 6 ayrı kabinden oluşan Salih Tüzün Bozbeyoğlu dijital kayıt stüdyosu 3 Aralık 2007 tarihinde fiilen hizmete girmiş ve gönüllü okuyucular tarafından okunan kitaplar bu tarihten itibaren dijital ortamda seslendirilmeye başlanmıştır. Ayrıca dijital ortama aktarılan bu kayıtlar 12 Aralık 2007 tarihinde 5846 sayılı Fikir ve Sanat Eserleri Kanunu'nun Ek 11. maddesince web ortamından görme engellilerin kullanımına açılarak hizmet vermeye başlamıştır. (http:// www.mkutup.gov.tr).

Milli Kütüphane Konuşan Kitaplık Bölümü'nde ikisi görme engelli, üç personel görev almaktadır. Personellerin arasında Bilgi ve Belge Yönetimi mezunu çalışan bulunmamaktadır. Milli Kütüphane tarafından bütçe sağlanarak görme engelli olan iki personel Hollanda ve İngiltere'ye gönderilmiştir. Bu gezi kapsamında DAISY (Digital Accessible Information System) görme engellilere yönelik erişilebilir kütüphanecilik sistemleri hakkında eğitim almışlardır. Bu kütüphanenin kendisini ve personelini geliştirmesi adına oldukça büyük bir adımdır.

Konuşan kitaplık için önemli bir yere sahip olan, seslendirme yapan bireylerin de hepsi gönüllü okuyuculardır. Bu görevi üstlenen bir personel yoktur. Bu da görme engelli kullanıcılar ve kütüphane için bir eksikliktir. Görme engellilerin gözleri olan gönüllü okuyucular ile kütüphane hayat bulabilmektedir. Çünkü onlar olmadan görme engelliler için kitaplara ses verecek, onların "bilgiye erişim" hakkını somutlaştıracak bir profesyonel okuyucu bulunmamaktadır. Gönüllü okuyucular ile kitaplar hayat bulmakta, görme engelli kullanıcılar için bir değere sahip olmaktadır. "Hiç görmeyen 
bir birey için bir kitap ne kadar bir şey ifade edebilir?" İçindeki bilgi ne kadar değerli olursa olsun o kitap görme engelli birey için anahtarı kaybolmuş bir hazine kutusudur. Değerli olduğunu bilirsin ama değerinin sana bir faydası olmaz. Bundan dolayı gönüllü okuyucular kütüphaneler için çok önemli bir yere sahiptirler. Gönüllü okuyucular kütüphaneye başvurduklarında stüdyolarda ses kayıt denemesi yapılmaktadır. Bunun için 3 dakikalık bir paragraf, tekerleme okutulmakta ve bu seslendirme kayıt altına alınmaktadır. Kütüphane personeli tarafından dinlenen bu ses kaydı Türkçeyi güzel konuşması, diksiyonun düzgün olması ve ses renginin kulağa hoş gelmesi gibi kriterler dikkate alınarak gönüllü okuyucu seçimi yapılmaktadır. Gönüllü okuyucuların istedikleri kitapları okumakta serbest olmaları olumsuz durumlar yaratmaktadır. Okuyucular daha çok roman gibi eserleri tercih etmekte, test kitaplarını, dil kitaplarını okumayı tercih etmemektedirler. Tamamen gönüllülük esaslı olmasına rağmen, gönüllü okuyucular seçildikten sonra mutlaka uymaları gereken belirli kurallar konulmalı ve okuyucular buna göre hareket etmelidir. Ayrıca gönüllü okuyuculara seslendirme yapmaya başlamadan önce özel kapsamlı eğitimler de verilmelidir. Ancak böyle özel kapsamlı bir çalışma, eğitim kütüphane bünyesinde yoktur (gönüllü okuyucu sayısı: 100).

Milli Kütüphane Konuşan Kitaplık Bölümü ara yüzü görme engellilere özel olarak Başbakanlık Özürlüler İdaresi "erişilebilirlik kriterlerine" göre hazırlanmıştır. Bu kapsamda ara yüz içersinde flash görüntü yani kayan yazı, görüntü, değişen renkler vb. unsurlar bulunmamaktadır. Genel olarak sitenin kullanımı basittir. Elektronik ortamda son eklenen kitaplar, bugün en çok dinlenen kitaplar, en çok okunan ilk beş kitap, şuanda seslendirilen kitaplar, duyurular, diğer görme engelliler kütüphanelerine erişebilmek için linkler yer almakta, gelişmiş arama da yapılabilmektedir. Ayrıca internette eserler kataloglanmıştır.

2001 yılında Konuşan Kitaplığın yenilenmesi, günün teknolojisine uygun hale getirilmesi için büyük bir proje başlatılmıştır. Bu doğrultuda gerçekleştirilen yenilikler şunlardır: Türkiye'de ilk kez akıllı teyp ve CD çalardan oluşan 8 kullanıcılı bir sistem kurulmuş ve görme engellilerin hizmetine sunulmuştur. Bu sistemde, kullanıcılar panellerde bulunan akıllı CD ve kasetçalarlar ile teyplerin ve CD çalarların üzerindeki düğmeleri tek tek aramaya gerek kalmadan klavye aracılığıyla işlemleri sesli olarak yapabilmektedir (Bakırcı, 2009, s.101-102). Fakat bu imkân kullanıcıların kütüphaneye gelmeyi tercih etmedikleri için günümüzde kullanılmamaktadır. Ayrıca kasetler de taşıma zorluğunun yaşanması, maliyetinin fazla olması, depolanması ve saklanmasının zor olması, kasetlere yapılan kayıtların yeterince kaliteli olmaması ve kolay bozulmaları gibi olumsuz özellikleri yüzünden günümüzde tercih edilmemekte yerlerini $C D^{\prime}$ lere bırakmaktadır.

Hizmetlerin çeşitlenmesinde ve kaynakların arttırılmasında başka kurumlar ile iş birliği yapılmaktadır. "Görme Engelli Kütüphaneleri Eşgüdüm Komitesi": Türkiye'de standart hizmet kalitesi bulunmayan görme engellilere yönelik kütüphane hizmetlerinin, eşgüdümünün ve standartlaştırılmasının sağlanması, kaynak israfının önlenmesi, bir 
yandan da görme engellilere etkin ve verimli bir kütüphanecilik hizmeti götürülmesi amacıyla Milli Kütüphane Başkanlığı Konuşan Kitaplık Görme Engelliler Merkezi'nin sekretaryalığını yaptığı bir komite oluşturulmuştur.

\section{Milli Kütüphane Dijital Arşiv Projesi}

Bu projenin hayata geçirilmesi ile gönüllü okuyucular tarafından çağdaş bir stüdyo ortamında okunan kitapların dijital ortama kaydedilip gelişmiş araçlarla düzenlenerek 5,5 terabytelık depolama ünitesi içerisinde, Metus Library arşivleme yazılımı vasıtası ile arşivlenmesi sağlanmış olacaktır. Arşivlenen bu dijital dosyalar, teknik standartlara ve mevzuata uygun olarak indeksleme bilgileri atandıktan sonra, gerek kütüphane içerisinde, gerekse kullanıcı dostu internet ara yüzü vasıtasıyla kütüphane dışından da erişime sunulacaktır. Kullanıcılar kitap adı, yazar adı, basım yılı, okunma tarihi, ISBN gibi erişim uçlarını kullanarak dinlemek istedikleri dosyaya kolayca ulaşabilecektir. Kitap istenirse gerçek zamanlı olarak dinlenebilecek, istenirse indirilebilecektir. İnternet üzerinden kitabı dinleyen kullanıcılar, dinlemeye daha sonra devam etmek üzere kaldıkları yere işaret koyabilecek ve sisteme tekrar bağlandıkları zaman bu işaretin olduğu yerden devam edebilme şansına sahip olabileceklerdir (Bakırcl, 2009, s.102103). Görme engelli kullanıcılara erişim rahatlığı sağlaması açısından oldukça önemli olan bu proje günümüzde kısmen hayata geçirilmiştir. Şuan da kullanıcılar dinlemeye daha sonra devam etmek üzere kaldıkları yere işaret koyabilmekte ve sisteme tekrar bağlandıkları zaman bu işaretin olduğu yerden devam edebilmektedirler. Ayrıca bu proje ile sesli kitapların arşivlenmesi, Milli Kütüphane'nin kuruluş amaçlarından olan "gelecek kuşaklara eserlerin aktarılmasını " görme engellilere yönelik koleksiyon dâhilinde de sağlanması mümkün olacaktır.

\section{Çalışmanın Amacı, Kapsamı ve Yöntemi}

Araştırma kapsamında Milli Kütüphane Konuşan Kitaplık Bölümü hizmetleri ve hizmet verdiği kullanıcı grubu olan görme engelli kullanıcıların gereksinimleri irdelenmeye çalışılmıştır. Bu araştırma, "Milli Kütüphane'de görme engellilere hizmet veren Konuşan Kitaplık Bölümü’nü ele alarak değerlendirmek, bu değerlendirmeler doğrultusunda kullanıcı memnuniyeti araştırması yapmak" amacıyla gerçekleştirilmiştir. Bu çerçevede araştırma hipotezimiz; "Milli Kütüphane Konuşan Kitaplık Bölümü görme engellilere yönelik hizmetleri yeterli olmadığı ortaya çıkmıştır" biçiminde oluşturulmuştur. Çalışma anket ve yüz yüze görüşme teknikleri* kullanılarak gerçekleştirilmiştir. Araştırmanın

\footnotetext{
Not: Anketlerden çıkan sonuçlar ile görüşme sırasındaki tutumlar birbiriyle çelişmektedir. Tutumların ve eleştirilerin çıkan sonuçlarından farklı olması durumunu anket yaptığımız kullanıcılara sorduğumuzda onlardan şu yanıtı aldık: "Hizmetlerinde, koleksiyonunda, personelinde, binasında, gönüllü okuyucularında, teknolojik alt yapısında olmak üzere birçok eksikliği var. Bundan dolayı kütüphaneyi eleştiriyoruz ancak kütüphaneye, personele özellikle de bu işi hiçbir ücret almadan yapan gönüllü okuyuculara vefa borcumuz da var. Milli Kütüphane olmasa şuan eleştirdiğimiz konuşan kitaplığa sahip olamayacak sesli kitaplara kolaylıkla erişemeyecektik. Bundan dolayı ankette bazı soruları duygusal olarak cevaplamış olabiliriz". Bizde çalışmamızın doğru olabilmesi için kullanıcı memnuniyetini değerlendirirken sadece anket sonuçlarını göz önünde bulundurmadık, yaptığımız görüşmelerde elde ettiğimiz bilgiler ışığında da genel değerlendirmeler yaptık.
} 
evreni olarak Milli Kütüphane Konuşan Kitaplık Bölümü üyeleri seçilmiştir. Anket ve yüz yüze görüşme yöntemiyle elde edilen veriler SPSS programıyla değerlendirilmiştir.

\section{Bulgular ve Değerlendirme}

Bu bölümde Milli Kütüphane'de bulunan görme engellilere hizmet veren Konuşan Kitaplık Bölümü'nü ele alınacak ve kullanıcı memnuniyeti araştırması yapmaya yönelik olarak uygulanan anket verileri değerlendirilecektir.

\section{Milli Kütüphane Konuşan Kitaplık Bölümü Üyelerinin Özellikleri}

Araştırmamız kapsamında görme engelli kullanıcıların özellikleri, cinsiyetleri, medeni durumları, gelir düzeyleri, yaş aralıkları, öğrenim durumları Milli Kütüphane Konuşan Kitaplık Bölümü'nde verilen hizmetleri doğru bir şekilde değerlendirmek için önemlidir.

Araştırma kapsamında anket uygulanan kullanıcıların \%65,6'sı erkek; \%34,4'ü bayandır. Kullanıcıların medeni durumları \%18,8'i evli; \%81,3'ü bekâr olarak saptanmıştır. Gelir düzeyleri ise $\% 12,5^{\prime} \mathrm{i}$ alt, $\% 81,3$ 'ü orta, $\% 6,3$ 'ü üst şeklindedir.

Anket uygulanan Milli Kütüphane Konuşan Kitaplık Bölümü kullanıcılarının büyük bir çoğunluğunu $(\% 37,5)$ 13-17 yaş aralığındaki ilköğretim öğrencileri oluşturmaktadır. Bunun sebebi anket uygulayabildiğimiz kullanıcıların çoğunluğunu ilköğretim okulu ve lise öğrencilerinin oluşturması ve bu yaş aralığındaki üyelerin daha çok kütüphaneyi kullanmasıdır. 18-29 yaş aralığında ki kullanıcı grubu da çoğunlukta olup \%34,4 oranındadır. İki kullanıcı grubu da ders kitapları, test kitapları gibi sesli kitapları en çok kullanan gruptur. Bu verilerden yola çıkarak Konuşan Kitaplık Bölümü hizmetlerini bu kullanıcı grubu üzerinde daha da yoğunlaştırmalıdır.

Anket uygulanan kullanıcıların $(\% 56,3)$ yarısından fazlası ortaöğretim öğrencisi olup Master-Doktora düzeyinde eğitim almış kullanıcı $(\% 6,3)$ ise neredeyse yoktur. Bunun nedeni de daha önce açıkladığımız gibi görme engelli kullanıcılara ilköğretim okulu ve lisede daha çok ulaşmış olmamızdır.

\section{Milli Kütüphane'nin Binasına İlişkin Durum}

Kütüphaneler de verilen hizmetlerin niteliğini etkiyen unsurlar arasında yer alan "bina" unsuru kullanıcılar için çok önemli bir yere sahiptir. Kullanıcıları için estetik olmayan, kullanışsız olan, kullanıcıların ihtiyaçlarını karşılamayan, kullanıcılara rahat bir ortam sunmayan bir kütüphane çok zor durumda kalmadıkça tercih edilmez. 
Tablo I. Kütüphanenin Binasına İlişkin Durum

\begin{tabular}{|c|c|c|c|c|c|c|c|c|}
\hline \multirow{2}{*}{ Binanın Durumu } & \multicolumn{2}{|c|}{ İyi } & \multicolumn{2}{|c|}{ Orta } & \multicolumn{2}{|c|}{ Kötü } & \multirow{2}{*}{$\begin{array}{c}\text { Toplam } \\
\text { Sayı }\end{array}$} & \multirow{2}{*}{$\begin{array}{c}\text { Toplam } \\
\%\end{array}$} \\
\hline & Sayı & $\%$ & Sayı & $\%$ & Sayı & $\%$ & & \\
\hline Bina genel olarak nasıl? & 8 & 25,0 & 5 & 15,6 & 5 & 15,6 & 18 & 56,2 \\
\hline Binanın iç donanımı? & 8 & 25,0 & 5 & 15,6 & 5 & 15,6 & 18 & 56,2 \\
\hline $\begin{array}{l}\text { Bina aydınlatma, ısınma, } \\
\text { havalandırma açısından? }\end{array}$ & 11 & 34,4 & 6 & 18,8 & 1 & 3,1 & 18 & 56,2 \\
\hline
\end{tabular}

$\mathrm{Bu}$ verilere baktığımızda binaya ilişkin durumla ilgili sorulara cevap vermeyen kullanıcılar $(\% 43,8)$ yarıya yakındır. Bunun sebebi kullanıcıların kütüphaneye gitmek yerine internet ortamında kütüphaneye erişimi tercih etmeleridir. Verilen cevaplar doğrultusunda kütüphaneye gitme imkânı bulan kullanıcının (18 kişi, \%56,2) binadan genel olarak memnun olduğu ankette bu soruya cevap veren 18 kişiden 5'inin de kütüphane binasını beğenmediği sonucu ortaya çıkmıştır. "Binanın iç donanımı nasıl?" sorusuna da aynı cevapları almış bulunmaktayız. Kullanıcılar açısından önemli olan aydınlatma, havalandırma, ısınma gibi faktörlerinde bu soruya cevap veren kullanıcıların çoğu $(\% 34,4)$ tarafından iyi bulunduğu anlaşılmaktadır (Tablo I.). Verilen cevaplar aydınlatma, ısınma, havalandırma gibi unsurların Milli Kütüphane tarafından dikkate alındığını göstermektedir.

Kullanılan Sesli Materyallerin Ses Kalitesinin, Milli Kütüphane'nin Internet Ortamının Nasıl Olduğu, Personelin Kullanıcıya Nasıl Davrandığına İlişkin Durum

Görme engelliler için "temel bilgiye erişim kaynağı" olan sesli materyaller görme engelli kullanıcıların bilgi gereksinimlerini gidermede en önemli kaynaktır. Bundan dolayı kütüphane kullanıcılarına en iyi hizmeti verebilmek için internet ortamının kalitesine dikkat etmeli bu konuyla ilgili, görevli olan birim devamlı olarak kütüphanenin internet ortamını takip etmelidir. Personel her kütüphane için çok önemli yere sahip olup kullanıcılarına en iyi şekilde hizmet vermeyi kendine ilke edinmelidir. 
Tablo II. Kullanılan Sesli Materyallerin Ses Kalitesine, Kütüphanenin İnternet Ortamına, Personelin Kullanıcıya Nasıl Davrandığına ilişkin Veriler

\begin{tabular}{lccccccccc}
\hline & \multicolumn{2}{c}{ İyi } & \multicolumn{2}{c}{ Orta } & & Kötü & Toplam & Toplam \\
\cline { 2 - 8 } & Sayı & $\%$ & Sayı & $\%$ & Sayı & $\%$ & Sayı & $\%$ \\
\hline $\begin{array}{l}\text { Sesli materyallerin ses } \\
\text { kalitesi nasıl? }\end{array}$ & 17 & 53,1 & 6 & 18,8 & 4 & 12,5 & 28 & 87,5 \\
$\begin{array}{l}\text { Personel size nasıl } \\
\text { davranıyor? }\end{array}$ & 19 & 59,4 & 4 & 12,5 & 0 & 0 & 23 & 71,9 \\
$\begin{array}{l}\text { Kütüphanenin internet } \\
\text { durumu nasıl? }\end{array}$ & 15 & 46,9 & 5 & 15,6 & 3 & 9,4 & 23 & 71,9 \\
\hline
\end{tabular}

Görme engelli kullanıcıların bilgi gereksinimlerini karşılamak için günümüz de en çok kullandıkları kaynak sesli materyallerdir dolayısıyla bunların ses kalitesi büyük bir önem taşımaktadır. Tablo II'de yer alan "sesli materyallerin ses kalitesi nasıl?"sorusuna cevap veren kullanıcıların yarısından fazlası $(\% 53,1)$ materyallerin ses kalitesinden memnundur. Bu da sesli materyallerin genel olarak iyi durumda olduğunu göstermektedir. Bu soruya kötü ve orta diye cevaplayan kullanıcılar ise bazı materyallerin anlaşılmadığı, bazı bölümlerinde ses bozuklukları olduğu ve okuyucuların telaffuzlarının anlaşılır olmadığı gerekçesi ile bu şekilde yanıt verdiklerini belirtmişlerdir. Kütüphaneyi kullanma ve kullanıcılara yardımcı olma yönünden diğer kütüphane personeline göre daha büyük sorumluluğu olan personelden kullanıcılar büyük bir oranda memnundur. Kötü diyen kullanıcının olmaması personelin bu konuda başarılı ve bilinçli olduğunu gösterir. Kütüphanenin internet durumundan ise kullanıcıların yarıya yakın bir kısmı $(\% 46,9)$ memnun olduğunu belirmiştir. \%71,9 oranında cevap aldığımız bu soru için kullanıcılardan \%9,4'ü kötü yanıtını vermiştir.

Çalışma Alanlarının Uygunluğu, Koleksiyonun Yeterliliği, Kaynaklara Erişim Durumu, Elektronik Ortam Erişimi ve Gönüllü Okuyuculardan Memnuniyet

Çalışma alanlarının uygunluğu, koleksiyonun yeterliliği, kaynakların erişim durumu, elektronik ortam erişimi, gönüllü okuyucu memnuniyeti araştırmamız açısından önem taşımaktadır. Buna ilişkin veriler Tablo III'de yer almaktadır: 
Tablo III. Çalışma Alanlarının Uygunluğu, Koleksiyonun Yeterliliği, Kaynakların Erişim Durumu, Elektronik Ortam Erişimi ve Gönüllü Okuyuculardan Memnuniyet

\begin{tabular}{|c|c|c|c|c|c|c|c|c|}
\hline & \multicolumn{2}{|c|}{ Evet } & \multicolumn{2}{|c|}{ Hayır } & \multicolumn{2}{|c|}{ Kısmen } & \multirow{2}{*}{$\begin{array}{c}\text { Toplam } \\
\text { Sayı }\end{array}$} & \multirow{2}{*}{$\begin{array}{c}\text { Toplam } \\
\%\end{array}$} \\
\hline & Sayı & $\%$ & Sayı & $\%$ & Sayı & $\%$ & & \\
\hline $\begin{array}{l}\text { Çalışma alanları } \\
\text { uygun mu? }\end{array}$ & 7 & 21,9 & 4 & 12,5 & 1 & 3,1 & 12 & 37,5 \\
\hline Koleksiyon yeterli mi? & 7 & 21,9 & 9 & 28,1 & 12 & 37,5 & 28 & 87,5 \\
\hline $\begin{array}{l}\text { Kaynaklar rahatlıkla } \\
\text { bulabiliyor mu? }\end{array}$ & 16 & 50,0 & 6 & 18,8 & 8 & 25,0 & 30 & 93,8 \\
\hline $\begin{array}{l}\text { İhtiyaç duyduğunuz } \\
\text { bilgilere elektronik } \\
\text { ortamdan } \\
\text { ulaşabiliniyor mu? }\end{array}$ & 15 & 46,9 & 4 & 12,5 & 6 & 18,8 & 25 & 78,1 \\
\hline $\begin{array}{l}\text { Gönüllü } \\
\text { okuyuculardan } \\
\text { memnun musunuz? }\end{array}$ & 19 & 59,4 & 1 & 3,1 & 10 & 31,3 & 30 & 93,8 \\
\hline
\end{tabular}

Tablo III verilerine göre; çalışma alanlarının uyguluğunu gösteren soruya çok az sayıda kullanıcının $(\% 37,5)$ yanıt verdiğini görmekteyiz. Kullanıcıların kütüphaneye gelmeyi tercih etmemeleri buna neden olmaktadır. Koleksiyonun yeterliliği hakkındaki soruyu yanıtlayan \%87,5'lik kullanıcıdan, çoğunluğu $(\% 37,5)$ kısmen yanıtını vermiştir. Bu da bize gösteriyor ki konuşan kitaplık bölümü koleksiyonu kullanıcıların koleksiyon gereksinimlerini tam anlamıyla karşılayamamaktadır. Kaynakların erişim durumu hakkında elde ettiğimiz verilere göre kullanıcıların yarısı (\%50) kaynaklara internet ortamında kolaylıkla erişebilmektedir. Elektronik ortamda erişimi ise yarıya yakın kullanıcı tarafından olumlu görülmüştür. Milli Kütüphane Konuşan Kitaplık Bölümü gönüllü okuyucular tarafından seslendirilen sesli materyallerden oluşmaktadır yani bu işi yapan özel bir personel yoktur. Kullanıcılar gönüllü okuyuculardan büyük oranda $(\% 59,4)$ memnundur. \%31,3 'lük kısmı ise gönüllü okuyucuların bazılarının telaffuzlarındaki olumsuzluklardan dolayı kısmen seçeneğini işaretlemiş bulunmaktadır.

\section{Personelin Görme Engelli Kullanıcıya Yardımı}

Kütüphanelerin niteliklerinin değerlendirilmesinde beş unsurdan biri olan personel araştırma kapsamız da önemli bir yer ve değer taşımaktadır. 
Tablo IV. Personellerin Kullanıcılara Yardımı

\begin{tabular}{lrc}
\hline Personel Yardımı & Sayı & $\%$ \\
\hline Tamamen & 15 & 46,9 \\
Kısmen & 5 & 15,6 \\
Hiç & 3 & 9,4 \\
\hline Toplam & 23 & 71,9 \\
\hline
\end{tabular}

Tablo IV'deki verilere baktığımızda soruyu cevaplayan kullanıcıların genel olarak personelin kendilerine tamamen $(\% 46,9)$ yardımcı oldukları sonucu ortaya çıkmaktadır.

\section{Profesyonel Okuyucular}

Görme engelliler için seslendirilen kitaplar gönüllü okuyucular tarafından okunmakta olup anket sorularımız içersin de "Profesyonel okuyucular ister misiniz? " sorusuna da yer vererek hem gönüllü okuyucular için daha iyi değerlendirme yapmak hem de böyle bir ihtiyacın olup olmadığını anlamak için bu soru sorulmuştur. Verilere göre, kullanıcılardan sadece bir kişi bu soruyu boş bırakmış; hayır diyen olmamıştır. Geri kalan 31 kullanıcı $(\% 96,9)$ ise profesyonel okuyucu olması gerektiğini düşünmektedir. Görme engelli kullanıcılar için seslendirilen bu kaynaklar iyi bir şekilde seslendirildikleri ölçüde yararlı olacaktır. Bundan dolayı profesyonel okuyucular çok önemlidir. Anket sonuçları ışığında da en çok öne çıkan en çok istenilen hizmetlerden biri profesyonel okuyucu ihtiyacının giderilmesidir.

\section{Kullanıcıların Aktif Olarak Kütüphaneyi Kullanma Sıklıkları}

Görme engelli kullanıcıların kütüphaneye gelme sıklıklarına dair veriler; kütüphaneye gelen kullanıcı sayısının $(\% 46,9)$ az olduğu ve bu kişilerin de genelde kütüphaneye "iki Ayda bir Kez Ve Daha Az" geldiklerini göstermektedir. Anketi cevaplayan kullanıcıların yarısından fazlası $(\% 53,1)$ ise kütüphaneye hiç gitmedikleri veya şuana kadar kütüphaneye çok az gittikleri için bu soruyu boş bırakmışlardır.

\section{Kütüphanenin Açılış Kapanış Saatleri}

Kütüphanenin açılış kapanış saatlerinin kullanıcıya uygunluğu kullanıcının kütüphaneyi kullanabilmesi açısından önemli bir yere sahiptir. Kullanıcıya uymayan saatler aktif olarak kütüphaneyi kullanmak isteyen kullanıcıları olumsuz yönde etkilemektedir. Veriler bize anketi cevaplayan kullanıcıların çok büyük bir kısmının $(\% 59,4)$ bu soruyu boş bıraktığını göstermektedir. Bunun nedeni diğer tablolarda sıkça belirttiğimiz gibi kullanıcıların kütüphaneye gelmeyi tercih etmemeleridir. Verilerden çıkan sonuca göre saatleri uygun bulan ve uygun bulmayan kişi sayısı birbirine yakındır. 
Kullanıcıların Genel OlarakMilli Kütüphane Konuşan KitaplıkBölümüne, Koleksiyonuna, Binasına ve Personeline Ilişkin Memnuniyet Verileri

Görme engelli kullanıcılar Milli Kütüphane Konuşan Kitaplık Bölümüne, binasına ve personeline ilişkin memnuniyet verileri aşağıdaki Tablo V'de yer almaktadır.

Tablo V. Kullanıcıların Konuşan Kitaplık Bölümü, Koleksiyon, Bina ve Personel Memnuniyetleri Durumu

\begin{tabular}{|c|c|c|c|c|c|c|c|c|}
\hline \multirow{2}{*}{ Memnuniyet } & \multicolumn{2}{|c|}{$A z$} & \multicolumn{2}{|c|}{ Orta } & \multicolumn{2}{|c|}{ Çok } & \multirow{2}{*}{$\begin{array}{c}\text { Toplam } \\
\text { Sayı }\end{array}$} & \multirow{2}{*}{$\begin{array}{c}\text { Toplam } \\
\%\end{array}$} \\
\hline & Sayı & $\%$ & Sayı & $\%$ & Sayı & $\%$ & & \\
\hline $\begin{array}{l}\text { Konuşan kitaplık } \\
\text { bölümünden } \\
\text { memnuniyetiniz? }\end{array}$ & 5 & 15,6 & 9 & 28,1 & 13 & 40,6 & 27 & 84,4 \\
\hline $\begin{array}{l}\text { Koleksiyondan } \\
\text { memnuniyetiniz? }\end{array}$ & 7 & 21,9 & 12 & 37,5 & 7 & 21,9 & 26 & 81,3 \\
\hline $\begin{array}{l}\text { Binadan } \\
\text { memnuniyetiniz? }\end{array}$ & 5 & 15,6 & 7 & 21,9 & 6 & 18,8 & 18 & 56,3 \\
\hline $\begin{array}{l}\text { Personelden } \\
\text { memnuniyetiniz? }\end{array}$ & 3 & 9,4 & 9 & 28,1 & 13 & 40,6 & 25 & 78,1 \\
\hline
\end{tabular}

Konuşan Kitaplık Bölümü'nden memnuniyet ile ilgili yönelttiğimiz soruya kullanıcıların büyük bir çoğunluğu $(\% 84,4)$ cevap vermiştir. Bu soru sonucunu daha iyi anlayabilmemiz için verileri "az ve orta" seçeneğini bir grup "çok" seçeneğini de bir grup olarak ele alırsak "az ve orta" seçeneğini \%43,7 "çok" seçeneğini ise "\%40.6"lık bir kullanıcı seçmiştir. Verileri bu şekilde değerlendirmemizin sebebi ise yarıya yakın bir kısmın konuşan kitaplık bölümünden az ve orta şekillerde memnun olduklarını aynı zaman da yarıya yakın diğer bir kısmın bu bölümden memnun olduğunu sonucu ortaya çıkmaktadır. " Koleksiyondan ne kadar memnunsunuz?" sorusunu ise anket cevaplayan 32 kullanıcıdan 26'sı cevaplamış 6 kullanıcı ise bu soruyu boş bırakmıştır. Soruyu boş bırakma sebepleri olarak da Milli Kütüphane Konuşan Kitaplık Bölümü'nün koleksiyonunu kullandıklarını ama çoğunlukla başka bilgi merkezlerinden yararlandıkları için Milli Kütüphane Konuşan Kitaplık Bölümü koleksiyonunun tamamı hakkında bilgi sahibi olmadıklarını belirtmişlerdir. Koleksiyondan memnun olan kullanıcı ile memnun olmayan kullanıcıların yüzdeleri $(\% 21,9)$ aynıdır. Koleksiyondan kısmen memnun olan kullanıcı grubu ise $(\% 37,5)$ az ve çok seçeneklerinden daha fazladır. Yani bu soruyu cevaplayan \%81,3'lük bir kısımdan yarıya yakını "orta" seçeneğini işaretlemiştir. Sonuçlar doğrultusunda koleksiyonun yetersiz olduğu anlaşılmaktadır. Bina memnuniyeti ile ilgili sorduğumuz soruda ise 14 kişi bu soruyu cevaplamamış 18 kişi bu soruya cevap vermiştir. Nedeni ise diğer tablolarda belirttiğimiz gibi kullanıcıların genel olarak 
uzaktan erişimi tercih etmeleridir. "Personelden ne kadar memnunsunuz ?"sorusuna 32 kullanıcıdan 25'i cevaplamıştır. Cevaplamayan grup ise kütüphaneye hiç gelmemiş personelle hiç görüşmemiş ya da sadece telefon aracılığıyla görüşmüş kullanıcılardır. Anketi cevaplayan \%78,1'lik kullanıc grubu içinde \%40,6'lık bir kısmın personelden memnun olduğu sonucu ortaya çıkmıştır.

\section{Görme Engelli Kullanıcıların En Çok Hangi Kaynaklardan Faydalandığı}

Hangi kaynaklardan daha çok yaralanıldığı sorusu kullanıcıların en çok hangi kaynakları kullanmayı tercih ettiklerini öğrenip buna göre koleksiyon geliştirme açısından önemli bir yere sahiptir. Kullanıcıların yararlandığı kaynaklar en çok kullanılan kaynaktan en az kullanılan kaynağa doğru sıralanışı; roman, inceleme-araştırma, LYS hazırlık, test kitapları ve soru bankası, ÜDS hazırlık, KPSS hazırlık, biyografi, şiir, tarih şeklindedir. Bu veriler ışığında en çok kullanılan kaynağın romanlar olduğu daha sonra da genel olarak çeşitli sınavlara yönelik hazırlık kitapları olduğu anlaşılmaktadır. Koleksiyona bu kaynaklardan çokça eklenmesi gerekmektedir.

\section{Kullanıcıların Olmasını İstediği Kaynaklar}

Görme engelli kullanıcıların olmasını istedikleri kaynaklar çoktan aza doğru şu şekilde sıralanmıştır: film seslendirmeleri, çözümlü test kitapları, LYS hazırlık kitapları, lise ders kitapları, bulmaca dergileri, spor dergileri, karikatür dergileri, tiyatro betimlemeleri ve komedi içerikli dergiler. En çok istenen kaynak film seslendirmesi olmuştur. Milli Kütüphane'de görme engelliler için böyle bir kaynak yoktur ve bu çok büyük bir eksikliktir.

\section{Kullanıcıların OImasını İstediği Diğer Hizmetler}

Anket sonucunda kullanıcıların olmasını istediği çok sayıda ve çeşitlilikte hizmet bulunmaktadır. Bunları şu şekilde çok istenenden daha az istenene doğru sıralayabiliriz: film seslendirmeleri, bilgisayar kursu, kullanıcılar için servis, sosyal aktiviteler, güncel duyuru hizmetleri, kabartma kitaplar, tiyatro betimlemeler, tiyatro ve sinema günleri, günlük gazeteler, kitap okuma günleri, müzik kursu, bilgilendirici ve eğitici etkinlikler, meslek edindirme kursları, dil kursları, seminer ve paneller, gönüllü okuyucular için eğitim kursları, tarihi ve bilimkurgu film seslendirmeleri, uluslar arası süreli yayınlar. Yine görüyoruz ki film seslendirmeleri büyük oranda istenmektedir. Ayrıca eğitici kurslara görme engelli kullanıcıların çok fazla ihtiyaçları olduğu anlaşılmaktadır. Ülkemiz genelinde görme engelliler için çok az sayıda sosyal aktiviteler yapılmakta olup Milli Kütüphane gibi büyük bir kurumun da bu alanda çalışma yapması anket sonuçlarına göre kullanıcılar tarafından beklenmektedir.

\section{Konuşan Kitaplık Bölümüne Verilen Puanlar}

Anketimizin son sorusu olan "Genel olarak Milli Kütüphane Konuşan Kitaplık Bölümü’ne kaç puan verirsiniz?" sorusuna cevap olarak verilen puanları "çok iyi", "iyi", ,orta", "kötü" 
şeklinde gruplandırırsak çok iyi "81-100", iyi "61-80", orta "41-60" ve kötü "20-40"dır. Bu gruplandırmaya göre çok iyi diyen kullanıcı sayısı 10, iyi diyen kullanıcı sayısı 14, orta diyen kullanıcı sayısı 6 ve kötü diyen kullanıcı sayısı 2'dir. Sonuçlara göre "çok iyi" ve "iyi" diyen kullanıcı grubu daha fazladır. Bu da Milli Kütüphane Konuşan Kitaplık Bölümü’nün puanlamaya göre iyi durumda olduğunu göstermektedir.

\section{Sonuç}

$\diamond$ Milli Kütüphane Konuşan Kitaplık Bölümü, Kütüphanecilik Hizmetleri Daire Başkanlığına bağlı olarak Kitap Dışı Materyaller Şubesi bünyesinde görev yapmaktadır. Bu durum da başka bir şube altında bulunduğu için; kendine ait özel bir bütçesinin olmaması nedeniyle hizmetlerin sunulması, kütüphanenin işleyişi, yerine getirilen görevler hakkında bazı aksaklıklar yaşamaktadır.

$\diamond \quad$ Braille matbaası bulunmamaktadır. Bu yüzden Braille kaynaklar sınırlı sayıda ve yetersizdir. Bulunan Braille kitaplar güncelliğini yitirmiştir. Güncel kaynakların alımı konusunda da hiçbir çalışma yapılmamaktadır.

$\diamond \quad$ Koleksiyon yetersizdir. Her alanda kaynak içermemektedir (dini kitaplar, bulmacalar, karikatürler, betimlenmiş gezi rehberleri...). Bir kütüphane koleksiyonunda muhakkak bulunması gereken referans kaynakları bulunmamaktadır. Koleksiyonda her bireyin ihtiyacı olan dergi, gazete gibi süreli yayınlar yer almamaktadır. Az gören kullanıcılar için büyük puntolu kaynaklar, görme engelli kullanıcılar tarafından çok fazla talep edilen film ve tiyatro seslendirmeleri koleksiyonda bulunmamaktadır.

$\diamond \quad$ Yayınevleri ve yazarlar ile yapılacak bir işbirliği sayesinde koleksiyon geliştirilebilir. Fakat böyle bir çalışma bulunmamaktadır.

$\diamond$ Kasetten dijital ortama aktarılmış kaynaklarda ses bozuklukları olduğu için kullanıcılar bu durumdan rahatsızlık duymaktadırlar.

$\diamond \quad$ Bina dışında ve içinde birçok merdiven bulunmakta ayrıca Konuşan Kitaplık Bölümü görme engelli kullanıcılar için ulaşılması zor bir yerde bulunmaktadır.

$\diamond \quad$ Görme engelli bireylere kütüphanecilik hizmetleri konusunda uzmanlaşmış, Bilgi ve Belge Yönetimi mezunu personel bulunmamaktadır.

$\diamond$ Yetersiz personel sayısından dolayı yürütülmesi zorunlu olan işler ancak yapılabilmektedir. Kullanıcılar için özel çalışmalar yapabilecek zaman kalmamaktadır.

$\diamond$ Görme engelliler için çok önemli yeri olan kullanıcı eğitimi verilmemektedir.

$\diamond \quad$ Tamamen gönüllü okuyucuların çabasıyla hizmetlerini sürdüren Konuşan Kitaplık Bölümü'nde bu işi yapabilecek profesyonel okuyucular ve teknolojik altyapı 
bulunmaması işlerin uzun sürmesine neden olmakta ve kullanıcılar da talep ettikleri kaynaklara çok uzun süre sonra ulaşabilmektedirler.

$\diamond$ Gönüllü okuyucuların sayısını arttırmak için herhangi bir çalışma yapılmamaktadır. Ayrıca gönüllü okuyucuların görevlerini daha iyi yapmaları için özel bir eğitim yoktur. Gönüllü okuyuculardan bazılarının ses tonları, diksiyonları, telaffuzları kullanıcıyı rahatsız etmektedir. Ayrıca gönüllü okuyucuların bu işi daha da hevesli yapmaya teşvik etmek adına herhangi bir çalışma yapılmamaktadır.

$\diamond$ Görme engellilere sosyal hayatlarında yardımcı olabilecek faaliyetler (müzik, dil ve bilgisayar kursları...) sunulmamaktadır. Diğer kullanıcılara sunulan film günleri, konferanslar, seminerler, paneller gibi hizmetler görme engelli kullanıcılara özel olarak verilmemektedir.

$\checkmark$ Gelişen teknolojiyi sistematik olarak takip edememektedir. Görme engelli kullanıcıların yararlanabilmesi için gerekli donanım ve yazılımın olduğu bilgisayarlar mevcut değildir. Günümüz teknolojisine uygun DAISY player gibi seslendirilen kitabın ses tonunu ayarlayan istediği sayfaya geçişi sağlayan sesi kullanıcın isteğine göre hızlandıran, yavaşlatan anlaşılmayan yerler için soru işareti koyabilen, önemli görülen yerlerin altını çizebilen teknolojik aletler kullanıcı hizmetine sunulmamaktadır.

$\diamond$ Görme engelli kullanıcıların çok büyük ihtiyacı olan servis hizmeti bulunmamaktadır.

$\diamond$ Millî Kütüphane Başkanlığı́n da “Işsbirliği ve Eşgüdüm Komitesi”nin yararlı çalışmaları bulunmaktadır. Ancak bu komitenin almış olduğu kararlar tam olarak uygulanmamaktadır. Bu komite de yer alan bazı kurumlar elindeki sesli kitapları ve seslendireceği kitapları tam olarak bildirmemiştir.

$\diamond$ Görme engelli kullanıcılar çoğunlukla kütüphaneyi kullanmamaktadır. Kullanmaya teşvik için özel bir çalışma yapılmamaktadır.

$\diamond$ İstatistiklerden elde ettiğimiz sonuca göre Türkiye'de çok sayıda görme engelli kullanıcı vardır. Bu kadar yüksek oranda görme engelli kullanıcı olmasına rağmen üye sayısı azdır. Üyelerini arttırmak için de herhangi bir çalışma yapılmamaktadır.

$\diamond$ Milli Kütüphane Konuşan Kitaplık Bölümü'nü hem görme engelli kullanıcılar hem de burada gönüllü okuyuculuk görevini yapabilecek olan bireylere konuşan kitaplığı tanıtmak adına herhangi bir reklâm ya da tanıtım yapılmamaktadır. Konuşan Kitaplık Bölümü'nün görme engelli kullanıcılar ve gönüllü okuyucu olmayı isteyen kişiler tarafından yeterince tanınmaması büyük bir eksikliktir. 
$\diamond$ Bu sonuçlara dayanarak şu öneriler sunulabilir:

$\diamond \quad$ Konuşan Kitaplık Bölümü'nün bağımsız ayrı bir bölüm olması, hukuksal açıdan bir kimliğe ve kendine ait bir bütçeye sahip olması gerekmektedir. Yasal bir statüye geçmesi sağlanmalıdır. Bunun için Milli Kütüphane Başkanlığı ilgili yerlerle görüşmelidir. Ayrıca kendisine ait hizmetlerini iyileştirmek ve geliştirmek için vizyonu ve misyonu olması gereklidir.

$\diamond$ Dünya Körler Birliği gibi alanında çok gelişmiş kurumlarla iş birliği yapıp, birlikte çalışmalıdır. Böylece uluslararası kuruluşların imkânlarından faydalanabilir ve kendini geliştirmek için hizmet ve olanaklarını gözlemleyip kendi kütüphanesine uygulayabilir.

$\diamond$ Milli Kütüphane bir arşiv niteliği de taşıdığı için yurt içindeki tüm sesli kitaplar Milli Kütüphane Konuşan Kitaplık arşivinde toplanmalıdır. Böylece ülkemizdeki tüm sesli kitaplar bir bütün halinde kayıt altına alınmış ve korunarak saklanmış olur.

$\diamond$ Koleksiyon çok yetersizdir ve arttırılmalıdır.

$\diamond \quad$ Koleksiyonlarının, kaynaklarının, hizmetlerinin daha iyi tanıtılması ve sunulması için kullanıcıları ile kütüphane devamlı olarak iletişim halinde bulunmalıdır.

$\diamond$ Braille matbaası satın alınmalıdır. Kitaplar hem seslendirilip hem de basılı hale getirilmelidir. Milli Kütüphane gibi amaç ve görevlerinden dolayı özel bir yere sahip olan bir kütüphanenin bunu kullanıcısı için temel gereksinim olarak görmesi gerekmektedir.

$\diamond \quad$ Hiç görmeyenler için Braille matbaası ile basılmış kaynaklar ve sesli kaynaklar olması gerekirken az görenler için de büyük punto ile basılmış basılı kaynaklar olmalıdır. Büyük punto ile basılmış hiçbir kaynak Milli Kütüphane koleksiyonunda yoktur ve bu büyük eksiklik mutlaka giderilmelidir.

$\diamond \quad$ Bir kitabın hem Braille hem büyük puntolu basımı hem de elektronik ortamda sesli kitap hali bulundurulmalıdır. Böylece kullanıcılara istedikleri materyallerden yararlanma fırsatı sunulmalıdır.

$\diamond$ Özellikle küçük yaştaki görme engelli kullanıcılar için nesnelerin, hayvanların, eşyaların betimlenmesi yapılmalı ya da kabartma tekniği kullanılarak basılı hale getirilmelidir.

$\diamond$ Büyüksan (2010, s.36)'ın Taylor (2004, s.58)'dan aktardığına göre dijital ekipmanın gelişmesiyle birlikte Braille materyaller, bilgisayara bağlanan ekranlar ve Braille klavyeler sayesinde okunabilmektedir. Bu sayede görme engelliler istedikleri bilgiye, yazılı materyale alternatif olarak bu araçlar sayesinde ulaşabilmektedir. Bu gibi teknolojik aletler kütüphane bünyesinde olmalı ve görme engelli kullanıcılar için özel çalışma odaları düzenlenmelidir. 
$\diamond$ Milî Kütüphane Konuşan Kitaplık Bölümü'nde teknolojik gelişmelerin takip edilmesine yönelik gerekli düzenlemeler mutlaka yapılmalıdır. Ekran okuma programları, ekran büyütme programları, Braille yazıcıları gibi teknik program ve araçlar mutlaka bulunmalıdır.

$\diamond$ Kullanıcıları ile doğru ve başarılı iletişime geçmek ve onlara gerçekten yararlı olabilmek için mesleğinin etik ilkelerini bilen, çalıştığı kuruma ve hizmet verdiği kullanıcı kesimine saygı duyan, görme engellilere yönelik teknolojik kütüphane hizmetlerini yakından takip eden bunları kullanmada yeterli olan, alanıyla ilgili güncel gelişmeleri yakından takip eden ve hizmet verdiği kullanıcı grubunun ihtiyaçlarını, özelliklerini bilen nitelikli personeller olmalıdır.

$\diamond$ Uzmanlaşmış nitelikli personel bulunmalı, Bilgi ve Belge Yönetimi mezunu personel görev almalıdır. Bilgi ve Belge Yönetimi Bölümü ile iş birliği yapılmalı, engellilere yönelik kütüphane hizmetleri ile ilgili ders verilmesi için taleplerde bulunulmalıdır.

$\checkmark$ Personel teknik sorunları çözme konusunda görme engelli kullanıcılarına yardım edebilecek durumda olmalı, görme engellilere yönelik bilgisayar programları konusunda bilgiye sahip olmalı ve bunun için de personele yönelik özel eğitim kursları olmalıdır.

$\diamond$ Profesyonel okuyucular bulunmalıdır.

$\diamond$ Profesyonel okuyuculuk yapacak bir personel yoktur ve bundan dolayı gönüllü okuyucular konuşan kitaplık için çok önemli yere sahiptir. Gönüllü okuyucular ses tonuna, diksiyonuna, telaffuzuna göre titizlikle seçilmelidir. Kelimeleri yutan, çok hızlı ya da çok yavaş okuyan, sesi kullanıcıyı rahatsız eden okuyucular seçilmemelidir. Aynı zamanda kabul edilen gönüllü okuyuculara kapsamlı eğitim kursları verilmelidir. Gönüllü okuyucuların teşviki ve hizmetlerinin devamı için küçük çaplı ödüllendirme amaçlı hediyeler, plaketler, bu görevi yaptığına dair teşekkür belgeleri verilmelidir.

$\diamond$ Bina içinde ve dışında görme engellilerin zorlanarak hareket etmelerine, vakit kaybetmelerine ve olası kazalara neden olacak çok sayıda merdiven bulunmaktadır. Aynı zaman da bina içinde Konuşan Kitaplık Bölümü'ne giderken birçok koridordan geçmek ve birçok merdiven inip çıkmak gerekmektedir. Bina dışındaki merdivenlerin yanına hafif eğimli iniş ve çıkışlar yapılmalı, ayrıca Konuşan Kitaplık Bölümü de binanın zemin katına merkezi bir yere taşınmalıdır.

$\diamond \quad$ Kütüphanede görme engellilerin rahatça ulaşabilecekleri ve yararlanabilecekleri bölümler halinde düzenlemeler yapılmalıdır. Az görenler için de özel aydınlatma sistemi kurulmalıdır(Kanık, 1994, s.78).

$\diamond$ Ülkemizde toplam mükerrer kitapları çıkardığımızda görme engellilerin hizmetine sunulacak 5000-6000 arasında çok az sesli kitap bulunmaktadır. Bu olumsuzluğu bir nebze ortadan kaldırabilmek için kütüphaneler arası ödünç verme işlemi 
yapılmalıdır. Ortak veri tabanları kurularak kullanıcıların daha fazla kaynağa erişimi sağlanabilecektir.

$\diamond$ Görme engellilere hizmet veren diğer kütüphaneler, dernekler, okullar, rehabilitasyon merkezleri, görme engellilere yönelik lisans, lisansüstü eğitim veren bölümlerle iş birliği yapmalı fikir alışverişinde bulunulmalıdır. Ayrıca hizmetlerini geliştirmeye, tanıtmaya, paylaşmaya yönelik seminerler, konferanslar, paneller düzenlenmelidir.

$\diamond \quad$ Kullanıcı ara yüzü geliştirilip görme engellileri yakından ilgilendiren konularda duyuru hizmetleri, güncel bilgiler gibi linklere yer verilmelidir.

$\diamond \quad$ Gezici kütüphaneler ile görme engelli kullanıcıların bulunduğu yerler tespit edilmeli kullanıcıların ayağına kadar hizmet götürülmelidir.

$\diamond$ Milli Kütüphane yeni çıkan yayınların yanında sesli kitap halinde CD'lerinin de verilmesi için yazarları ve yayıncıları teşvik etmeli bunu görme engelliler için bir reklâm kampanyası haline dönüştürmelidir.

$\diamond$ Devlet Tiyatroları stajyer sanatçıları ile TRT ve Basın Yayın Enformasyon Genel Müdürlüğü dil uzmanlarınca Türkçe ve yabancı dilde okuma yapılmalıdır. RTÜK aracılığıyla, ulusal düzeyde yayın yapan TV ve radyo sunucularının yılda en az bir kez ses kaydı amaçlı kitap okumaları teşvik edilmelidir. TRT ve Anadolu Üniversitesi işbirliğiyle hazırlanan TRT televizyonları ve radyolarında yayınlanan ders programlarının CD’lerinin Milli Kütüphane Başkanlığı'na gönderilmesi sağlanmalıdır. TRT ve özel radyolarda yayınlanan roman, öykü ve şiirlerin Milli Kütüphane arşivine kazandırılması sağlanmalıdır (Bakırcı, 2009, s.104).

$\diamond$ Tanıtım ve reklâm faaliyetleri yapılmalıdır. Örneğin kitap ayraçları, broşürler hazırlanmalıdır. Özellikle gönüllü okuyucu olmak için vakti ve ilgisi olan bireyler tespit edilmeli tanıtım ve faaliyetler sözü edilen bireylerin bulunduğu çevrelerde daha çok yapılmalıdır. Bu grup gözlemlerimize ve edindiğimiz bilgilere göre emekli olan bireyler ya da bu işe hevesli olabilecek üniversite öğrencileridir. Emekli olan bireylerin vakit geçirdiği hobi kurslarına gidip bu konu hakkında bilgi verilebilir, kitap ayraçları dağıtılabilir ayrıca bu kurslara dikkat çekici broşürler asılabilir. Üniversite öğrencileri için de üniversite kütüphanesine, kafeteryalara, yemekhanelere, kantinlere, bölümlere broşürler asılabilir, kitap ayracı dağıtılabilir aynı zaman da öğrencileri bilgilendirmek için kütüphane personeli de okulları ziyaret edebilir. Tanıtım ve reklâm faaliyetleri sadece gönüllü okuyucular için olmamalı aynı zamanda görme engelli bireyler için de yapılmalıdır. Çalışma kapsamında görüştüğümüz görme engelli bireylerden bazıları böyle bir hizmetin verildiğinden dahi haberdar değillerdir. Görme engelli bireyler tespit edilerek onlarla iletişime geçilebilir ya da görme engellilere yönelik hizmet veren dernek ve rehabilitasyon merkezleri ile işbirliği yapıp Milli Kütüphane Konuşan Kitaplık Bölümü hakkında bilgi verilebilir. 


\section{Kaynakça}

Bakırcı, R. (2009). Milli Kütüphane'de görme engellilere sunulan hizmetler ve gelişmeler. Bilgi Dünyası, 10(1), 100-104

Büyüksan, F. Y. (2009). Görme engellilere yönelik konuşan kitaplık hizmetinin geliştirilmesi: Milli

Kütüphane örneği. Yayınlanmamış uzmanlık tezi.

Çanak Akbaytürk, T. (2005, 22-24 Aralık). Kütüphanelerde kullanıcı memnuniyeti anketleri: Koç üniversitesi Suna Kıraç kütüphanesi deneyimi. ÜNAK'05 Bilgi Hizmetlerinin Organizasyonu ve Pazarlanması konferansında sunulan bildiri. http://kaynak.unak.org.tr/bildiri/unak05/u05-20. pdf adresinden erişildi.

Özkan, M. (2001). Görme engellilere yönelik eğitim kurumlarında mekansal problemlerin irdelenmesi ve çözüm önerileri. Yayınlanmamış Yüksek Lisans Tezi. Dokuz Eylül Üniversitesi, Fen Bilimleri Enstitüsü, İzmir.

Halk kütüphaneleri hizmeti: IFLA/UNESCO ilkeleri (2004). (B. Yılmaz Çev.). İstanbul: TKD İstanbul Şubesi.

Kanık, L. (1994). Görme engellilere yönelik kütüphane hizmetleri. Yayınlanmamış yüksek lisans tezi Hacettepe Üniversitesi, Ankara.

Kaynar, M.(1992).Görme özürlüler için kütüphane hizmeti. Türk Kütüphaneciliği, 6(2),114-117.

Kazak, M. (2008). Görme engellilere yönelik kütüphanecilik hizmetlerinde Türkiye'deki son gelişmeler: Gazi Üniversitesi merkez kütüphanesi görme engelliler bolumu örneği. Türk Kütüphaneciliği, 22(2), 216 - 221.

Subaşığlu, F. (2007). Görme engellilere yönelik kütüphanecilik ve ders programları. Ulusal Körler ve Kütüphanecilik Sempozyumu: Bitmeyen Gece Doç. Dr. Mithat Enç Anısına 16-17 Ekim 2007. Ankara.

Tunçkanat, H. (1990). Ulusal bilgi birikiminin denetlenmesi ve ulusal kütüphanemiz. Türk Kütüphaneciliği, 4(4), 170-174.

Özmen, B.B. (2005). Görme engelliler için konut iç mekanları ve donatı elemanlarının tasarım ve biçimlenişi. Yayınlanmamış yüksek lisans tezi Hacettepe Üniversitesi, Ankara.

Yılmaz, B. (2009). Bilgi ve belge yönetiminde (kütüphanecilikte) etik: kuramsal bir yaklaşım. Kamu Etiği Sempozyumu 25-26 Mayıs 2009 TODAiE/Ankara içinde (ss.395-404). Ankara: TODAiE.

Yılmaz, E. (2004, 11-13 Şubat). Üniversite kütüphanelerinde web tabanlı kullanıcı memnuniyeti ölçümü. Akademik Bilişim 2004 (Karadeniz Teknik Üniversitesi, 11- 13 Şubat, Trabzon) Konferansı'nda sunulan bildiri. http://ab.org.tr/ab04/program/7.html adresinden erişildi. 